\title{
PENERAPAN LITERASI LINTAS KURIKULUM \\ MATEMATIKA DALAM PEMBELAJARAN KELAS TINGGI \\ DI MIT NURUL ISLAM NGALIYAN SEMARANG \\ TAHUN 2016
}

\author{
Kristi Liani Purwanti, S.Si, M.Pd \\ Jurusan PGMI UIN Walisongo \\ Email : kristi_liani@walisongo.ac.id
}

\begin{abstract}
Abstrak
Pembelajaran di sekolah dasar atau madrasah ibtidaiyah merupakan pembelajaran yang sangat penting, sebab sebagai dasar dari pembelajaran seterusnya sampai jenjang perguruan tinggi. Pembelajaran yang diajarkan tidak boleh asal-asalan. Pembelajaran aktif kreatif efektif dan menyenangkan merupakan pembelajaran harus diterapkan. Salah satu ketrampilan yang ada dalam kurikulum 2013 yaitu kketrampilan literasi. Literasi merupakan keterampilan yang sangat dibutuhkan oleh siswa dalam proses belajarnya. Sebagai alat komunikasi dan alat belajar (means of communications dan learning tools), literasi perlu dikembangkan secara konsisten agar siswa tidak mengalami kesulitan dalam proses belajarnya. Penelitian dilakukan di kelas 4 dan 5 MIT Nurul Islam. Penerapan literasi lintas kurikulum matematika dalam pembelajaran kelas 4 hanya pada materi tertentu, misalnya mengidentifikasi sifat-sifat bangun ruang. Penerapan literasi lintas kurikulum matematika dalam pembelajaran kelas 5 hanya pada materi tertentu, misalnya mengidentifikasi sifat-sifat bangun datar, pengukuran skala.
\end{abstract}

Kata Kunci: Literasi lintas kurikulum Matematika; kelas tinggi; MIT Nurul Islam.

\section{PENDAHULUAN}

Pembelajaran merupakan salah satu unsur penentu baik tidaknya lulusan yang dihasilkan oleh suatu sistem pendidikan. Pembelajaran ibarat jantung dari proses pendidikan. Pembelajaran yang baik cenderung menghasilkan lulusan dengan hasil belajar yang baik pula.

Pembelajaran di sekolah dasar atau madrasah ibtidaiyah merupakan pembelajaran yang sangat penting, sebab sebagai dasar dari pembelajaran seterusnya sampai jenjang perguruan tinggi. Pembelajaran yang diajarkan tidak boleh asal-asalan. Pembelajaran aktif kreatif efektif dan menyenangkan merupakan pembelajaran harus diterapkan.

USAID PRIORITAS melatih guru-guru madrasah ibtidaiyah dan sekolah dasar yang merupakan mitra LPTK dari UIN Walisongo dan UNNES. USAID PRIORITAS 
sudah melakukan 2 kali pelatihan yaitu modul 1 dan modul 2. Modul 1 berisi tentang apa mengapa PAKEM, menciptakan lingkungan belajar yang efektif, persiapan mengajar PAKEM, KKG, RTL. Modul 2 berisi tentang kajian ulang PAKEM, mengelola pembelajaran yang efektif, memahami kurikulum, melayani perbedaan individu, pertanyaan tingkat tinggi, penilaian autentik, gender dalam pendidikan, literasi lintas kurikulum bahasa Indonesia, matematika, IPA dan IPS, persiapan mengajar, RTL. Ada 6 MI mitra LPTK UIN Walisongo yaitu MIT Nurul Islam Ngaliyan, MI Darul Ulum, MIN Sumurrejo, MI Walisongo, MI Miftakhul Akhlaqiyah, MI Miftahus Sibyan. MIT Nurul Islam Ngaliyan Semarang merupakan madrasah yang cukup besar dimana siswa sangat banyak, letak madrasah dipinggir jalan. Karena siswanya yang sangat banyak mempunyai 3 lokasi. Madrasah ini didukung guru-guru yang linear lulus dari jurusan PGMI. Guru-guru MIT Nurul Islam mendapatkan pendampingan dari peneliti.

Salah satu unit yang berisi literasi lintas kurikulum merupakan, pengetahuan yang baru bagi guru-guru MI. Dimana dalam unit itu menekankan literasi yang harus diterapkan di sekolah. Literasi merupakan keterampilan yang sangat dibutuhkan oleh siswa dalam proses belajarnya. Sebagai alat komunikasi dan alat belajar (means of communications dan learning tools), literasi perlu dikembangkan secara konsisten agar siswa tidak mengalami kesulitan dalam proses belajarnya. Bentuk-bentuk literasi yang perlu dikembangkan adalah mendengarkan, berbicara, membaca dan menulis. Literasi lintas kurikulum dalam bahasa Indonesia, matematika, IPA dan IPS, dapat diterapkan di semua Standar Kompetensi dan Kompetensi Dasar.

Setelah MIT Nurul Islam mendapatkan pelatihan modul 1 dan modul 2 serta mendapatkan pendampingan dari fasilitator LPTK UIN Walisongo Semarang, peneliti tertarik untuk meneliti "Penerapan Literasi Lintas Kurikulum: Matematika dalam Pembelajaran Kelas Tinggi di MIT Nurul Islam Ngaliyan Semarang tahun 2016”

\section{PEMBAHASAN}

\section{Pembelajaran Literasi}

Pembelajaran bahasa indonesia di sekolah dasar atau madrasah ibtidaiyah, siswa harus mampu menguasai 18 genre teks yaitu Teks pidato persuasif, Teks penjelasan, Teks laporan investigasi, pengamatan, informatif, Teks pantun dan syair, Teks papan iklan, Teks laporan/usulan buku, Teks wawancara, Teks instruksi/ arahan/ petunjuk, Teks permainan/ dolanan daerah, Teks dogeng, Teks surat tanggap pribadi, Teks 
permintaan maaf, Teks lirik puisi, Teks buku harian, Teks cerita sederhana, cerita diri, cerita petualangan, Teks cerita fiksi sejarah, Teks diagram, Teks deskriptif.

Sejalan dengan perkembangan konsep literasi yang terjadi, tujuan pembelajaran literai pun mengalami perubahan. Pembelajaran literasi ditujukan agar siswa mampu menguasai dimensi bahasa dan dimensi kognitif literasi (mencakup proses pemahaman, prosen membaca, proses menulis, dan konsep analisis wacana tertulis) (Abidin Y, 2015).

Berdasakan dokumen pada tahun 1998 dari The National Literacy Strategy, pembelajaran literasi ditujukan agar siswa mampu mencapai kompetensi-kompetensi sebagai berikut:

1. Percaya diri, lancar, dan paham membaca dan menulis

2. Tertarik pada buku-buku, menikmati kegiatan membaca, mengevaluasi dan menilai bacaan yang dibaca.

3. Mengetahui dan memahami berbagai genre fiksi dan puisi.

4. Memahami dan mengakrabi struktur dasar narasi.

5. Memahami dan menggunakan berbagai teks nonfiksi

6. Dapat menggunakan berbagai macam petunjuk baca (fonik, gratis, sintaksis, dan konteks) untuk memonitor dan mengkoreksi kegiatan membaca secara mandiri.

7. Merencanakan, menyusun draf, merevisi, dan mengedit tulisan secar mandiri.

8. Memiliki ketertarikan terhadap kata dan maknanya dan secara aktif mengembangkan kosakata.

9. Memahami sistem bunyi dan ejaan dan menggunakannya untuk mengeja dan membaca secara akurat.

10. Lancar dan terbiasa menulis tulisan tangan. (Wray, 2004)

Memasuki abad ke-21, pembelajaran literasi memiliki tujuan utama untuk memberikan kesempatan atau peluang kepada siswa dalam mengembangkan dirinya sebagai komunikator yang kompeten dan multikonteks, multikultural, dan multimedia melalui pemberdayaan multiintelegensi yang dimilikinya. Menurut Abidin (2015) Pembelajaran literasi pada abad ke-21 memiliki tujuan sebagai berikut:

1. Membentuk siswa menjadi pembaca, penulis, dan komunikator yang strategis.

2. Meningkatkan kemampuan berpikir dan mengembangkan kebiasaan berpikir pada siswa.

3. Meningkatkan dan memperdalam motivasi belajar siswa. 
4. Mengembangkan kemandirian siswa sebagai seorang pembelajar yang kreatif, inovatif, produktif, dan sekaligus berkarakter.

Keempat tujuan pembelajaran literasi di atas saling berhubungan dan saling memperkuat satu sama lain. Selain itu, keempat tujuan pembelajaran literasi tersebut bukan hanya diperuntukkan bagi bidang bahasa melainkan untuk berbagai bidang ilmu yang lain. Dengan kata lain, tujuan pembelajaran literasi diatas bersifat lintas kurikulum bahkan bersifat multiliterat.

Kemampuan literasi adalah salah satu kebutuhan yang sangat penting untuk dimiliki setiap orang. Ketrampilan literasi merupakan ketrampilan membaca, berbicara, menulis dan menyimak.

Pengertian kompetensi lintas kurikulum pada hakikatnya merupakan pengetahuan, ketrampilan, sikap, dan nilai-nilai yang direfleksikan dalam kebiasaan berfikir dan bertindak, baik mencakup kecakapan belajar sepanjang hayat maupun kecakapan hidup yang harus dikuasai oleh peserta didik melalui pengalaman belajar secara berkesinambungan.

\section{Literasi Lintas Kurikulum: Matematika}

Literasi merupakan keterampilan yang sangat dibutuhkan oleh siswa dalam proses belajarnya. Sebagai alat komunikasi dan alat belajar (means of communications dan learning tools), literasi perlu dikembangkan secara konsisten agar siswa tidak mengalami kesulitan dalam proses belajarnya. Bentuk-bentuk literasi yang perlu dikembangkan adalah mendengarkan, berbicara, membaca dan menulis. Semakin baik keterampilan literasi dimiliki oleh seorang siswa, semakin baik pula keterampilan belajarnya untuk mencapai kompetensi matematika yang diharapkan.

Literasi matematika didefinisikan sebagai kemampuan seseorang individu merumuskan, menggunakan, dan menafsirkan matematika dalam berbagai konteks. Termasuk di dalamnya bernalar secara matematis dan menggunakan konsep, prosedur, fakta, dan alat matematika dalam menjelaskan serta memprediksi fenomena. Dengan demikian literasi matematika membantu seseorang untuk mengenal peran matematika dalam dunia dan membuat pertimbangan maupun keputusan yang dibutuhkan sebagai warga negara (OECD, 2010). Pengertian literasi matematika PISA ini sejalan dengan Standar Isi (SI) mata pelajaran matematika.

Berdasarkan OECD (2000) literasi matematika meliputi 3 aspek yaitu (1) Proses: kemampuan untuk merumuskan dan menyelesaikan masalah matematika serta 
berproses mengarah pada matematika; (2) Isi: berkaitan dengan topik matematika: perubahan, pertumbuhan, keruangan, dimensi tiga, peluang, dll; (3) Latar/Konteks: berkaitan dengan kemampuan untuk menggunakan matematika pada lingkungan yang berbeda seperti sekolah, lingkungan pekerjaan dan rekreasi, komunitas lokal, dan masyarakat sekitar (Tai, C., Leon,S., and Hung, J. 2014)

Di dalam pembelajaran matematika, penerapan keterampilan literasi akan berpengaruh terhadap pemahaman konsep siswa. Saat siswa diminta untuk menerangkan suatu konsep, di kesempatan itulah guru memperoleh informasi sejauh mana siswanya memahami konsep tersebut. Guru dengan mudah bisa segera memberi masukan saat itu juga apabila siswanya melakukan kesalahan atau terjadi miskonsepsi.

Berikut adalah beberapa cara untuk mengembangkan pemahaman konsep matematika dengan memanfaatkan keterampilan literasi siswa:

1). Menyampaikan suatu masalah

2). Menjelaskan Jawaban

3). Menjelaskan Jawaban Yang Salah

4). Membuat Soal

Ada 2 strategi didalam literasi matematika yang dapat digunakan yaitu

1) Strategi I - Lima langkah Pemandu

a. Bacalah soal, tinggalkan kata-kata sulit

b. Apa yang ditanyakan soal?

c. Tulis yang ditanyakan soal

d. Sampaikan bagaimana menemukan jawabannya

e. Tulis jawabannya

2) Strategi $2:$ menggunakan potongan kertas

a. Bacalah soal

b. Tugas Individu: Pahami setiap pertanyaan/pernyataan dengan menulis ulang, menggambar atau menulis simbol di bawah setiap pertanyaan/pernyataan tersebut.

\section{Penerapan literasi lintas kurikulum: Matematika}

Berikut adalah beberapa cara untuk mengembangkan pemahaman konsep matematika dengan memanfaatkan keterampilan literasi siswa:

(a) Menyampaikan suatu masalah 
Siswa bisa diminta untuk menyampaikan suatu masalah dan menuliskannya. Misalnya, setelah mempelajari suatu konsep, siswa bisa diminta untuk menyampaikan soal dari buku, PR atau lainnya dan diminta untuk menyampaikannya dengan bahasa sendiri. Siswa juga kemudian diminta untuk menyampaikan bagaimana mereka menemukan jawabannya.

\section{(b) Menjelaskan Jawaban}

Siswa diminta untuk menjelaskan jawaban yang mereka peroleh dari suatu soal. Mereka diminta untuk menjelaskannya secara tertulis.

\section{(c) Menjelaskan Jawaban Yang Salah}

Siswa diminta memperbaiki jawaban yang salah. Mereka diminta menjelaskan mengapa jawaban salah, bagaimana memperbaikinya dan apa yang dilakukan agar mereka tidak mengulangi hal yang sama di masa mendatang.

\section{(d) Membuat Soal}

Setelah mempelajari suatu konsep, siswa diminta untuk membuat soal cerita sendiri dan meminta temannya untuk menemukan jawabannya. Setelah selesai, mereka saling mengecek jawaban dan saling menjelaskannya. Apabila ada siswa yang salah menjawab, siswa lain bisa menjelaskan konsepnya sekali lagi.

Pembelajaran matematika di kelas 3, belum begitu jalan sebab guru kelas 3 tergolong baru dan baru sekali mengikuti 1 kali mengikuti pelatihan, materi materi dalam pelatihan belum semua dilakukan diterapkan, penerapan yang dilakukan pembelajaran aktif belum menggunakan ketrampilan literasi.

Pembelajaran matematika di kelas 4, yang menggunakan ketrampilan literasi saat mencari konsep dasar sifat-sifat bangun ruang balok dimana pembelajarannya adalah memanfaatkan kardos snack. Siswa diajak menemukan sendiri sifat-sifat balok yaitu ada berapa sisi bangun balok dengan menunjukkan pada benda, ada berapa rusuk bangun balok dengan menunjukkan pada benda, titik sudut ada berapa dengan menunjukkan pada balok. Setiap kelompok akan mempresentasikan hasil dari penemuan itu didepan kelas. Siswa bertanya hal-hal yang belum diketahui atau belum jelas saat pembelajaran. Pembelajaran akhir siswa dapat membuat peta konsep dari pembelajaran hari ini. Pembelajaran matematika kelas 4 dengan menggunakan ketrampilan literasi hanya materi-materi tertentu, belum semua materi menggunakan ketramoilan literasi. 
Pembelajaran matematika kelas 5 yang menggunakan ketrampilan berliterasi yaitu mengidentifikasi bangun ruang dengan model pembelajaran indeks card match, satu kelas dibagi menjadi 4 kelompok besar, dalam 1 kelompok mendapatkan tugas yang sama yaitu menebak bangun datar apa yang ada dalam kartu, siswa yang memberikan pertanyaan hanya memberikan deskripsi sifat-sifat bangun datar. Kelompok yang lain memperhatikan kelompok yang maju. Kartu disiapkan dalam satu tumpukan, siswa berbaris yang akan memberikan pertanyaan maju kedepan ambil satu kartu menghadap temannya dengan memberikan deskripsi singkat sifat bangun datar yang akan menjawab kosentrasi mendengarkan jawaban, hanya boleh menjawab 1 jawaban, jawaban salah atau dia maju menjadi penanya sampai semua siswa bertanya dan menjawab serta waktu ditentukan oleh guru. Jawaban yang salah ditumpuk lagi, jawaban yang benar diptempel pada plano yang disiapkan oleh guru. Setelah kelompok 1-4 semuanya melakukan tanya jawab. Guru akan menilai dari jawaban yang benar yang ditempel, guru akan memberikan reward bagi kelompok yang paling banyak menempel kartu di plano. Guru melakukan refleksi tentang hal-hal yang belum dipahami. Kegiatan akhir siswa menulis ulang tentang sifat-sifat bangun datar pada peta konsep yang disediakan oleh guru.

Pembelajaran matematika juga diterapkan dalam soal cerita menggunakan strategi 2 : menggunakan potongan kertas

a). Bacalah soal

b) Tugas Individu: Pahami setiap pertanyaan/pernyataan dengan menulis ulang, menggambar atau menulis simbol di bawah setiap pertanyaan/pernyataan tersebut.

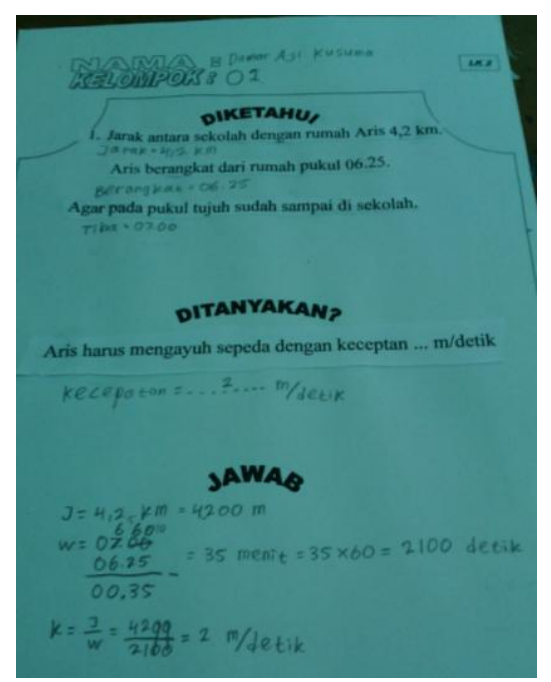


Dengan menggunakan strategi potong kertas merupakan hal yang efektif dalam pembelajaran matematika terutama soal cerita. Strategi ini digunakan dalam soal materi kecepatan. Dari soal di potong-potong ditempel pada 3 aspek yang disediakan adalah diketahui, ditanya dan dijawab. Setelah diletakkan pada 3 aspek itu, setiap kalimat harus diberi jarak untuk menyelesaikan jawabannya. Jika sudah selesai dari tiga aspek dijawab makan selesai pula pertanyaan soal cerita. Strategi ini mempermudah anak dalam menyelesaikan soal cerita.

Pembelajaran matematika di kelas 5 materi skala, dimana pembelajaran ini adalah menemukan konsep dari skala. Guru menjelaskan langkah-langkah apa saja yang akan dilakukan siswa untuk menemukan konsep skala, yang pertama siswa faham dulu bagaimana mengukur sebuah benda. Siswa dibagi beberapa kelompok tugas kelompok berbeda-beda. Matematika yang digunakan adalah dalam kehidupan sehari-hari. Tugas kelompok 1,2,3 adalah mengukur panjang dan lebar dari ruang perpustakaan dan kelompok 4,5,6 bertugas mengukur panjang dan lebar dari ruang kelas sendiri. Setelah mereka melakukan pengukuran maka siswa harus bisa menuangkan ukuran itu dalam gambar di atas plano. Disinilah anak akan berpikir dengan ukuran sebenarnya dan ukuran pada gambar. Setelah dapat menuangkan gambar ruangan pada plano, perwakilan dari kelompok ada yang mempresentasikan hasilnya. Setelah guru memberikan reward kepada siswa, guru melakukan refleksi, guru memberikan selembar kertas untuk setiap siswa untuk membuat sebuah cerita tentang pembelajaran yang dilakukan hari ini, yang penting adalah konsep dari skala.

\section{KESIMPULAN}

Berdasarkan uraian dari keseluruhan pembahasan diatas dapat disimpulkan bahwa penerapan literasi lintas kurikulum matematika dalam pembelajaran kelas 4 hanya pada materi tertentu, misalnya mengidentifikasi sifat-sifat bangun ruang. Penerapan literasi lintas kurikulum matematika dalam pembelajaran kelas 5 hanya pada materi tertentu, misalnya mengidentifikasi sifat-sifat bangun datar, pengukuran skala.

\section{DAFTAR PUSTAKA}

Abidin, Yunus. 2015. Pembelajaran Multiliterasi. Bandung: Refika Aditama. 
Ali, Mohamad. 1992. Penelitian Pendidikan Prosedur dan Strategi. Bandung: Angkasa Bandung.

Arikunto, Suharsimi. 2006. Penelitian Tindakan Kelas. Jakarta: PT Bumi Aksara.

Departemen Pendidikan Nasional. 2003. Kurikulum Berbasis Kompetensi, Pendidikan

Prasekolah, Dasar, Menengah: Ketentuan Umum. Jakarta : Depdiknas.

------------. Kurikulum 2004, Pengetahuan Sosial Sekolah Dasar dan Madrasah Ibtidayah. Jakarta: Depdiknas.

Deddy Mulyana, 2010, Metodologi Penelitian Kualitatif, Bandung: PT. Remaja Rosdakarya, hlm. 156-157

Karim, Abdul Muchtar, Dkk. 2014. Pendidikan Matematika 2. Jakarta:Universitas Terbuka.

Karso, Dkk. 2014. Pendidikan Matematika 1. Jakarta:Universitas Terbuka.

Khikmayanti, Arfo. http: //journal.unnes.ac.id/sju/index.php/chemined/article/view/933

Kuhthau, C.C., Maniotes, L.K., dan Caspari, A.K. (2007) Guide Inquiry: Learning in The 21st Century. London: Libraries Unlimited.

Nana Sudjana dan Ibrahim, 1989, Penelitian dan Penelitian Pendidikan, Bandung: Sinar Baru, , hlm. 64

Nusa Putra. 2012. Penelitian Kualitatif, Jakarta: PT Indeks, 2012, hlm. 189

OECD. 2010. Matemathics Framework. (Paris: PISA, OECD Publishing, 2009), hlm. 4.

Poerwanti, Endang. 2007. Asesmen Pembelajaran. Jakarta : Depdiknas.

Purniati, Tia. 2009. Matematika. Jakarta: Direktorat Jenderal Pendidikan Islam.

Sutardhi. 2003. Konsep Dasar IPA .Semarang: Universitas Negeri Semarang.

Tai, C., Leon,S., and Hung, J. 2014. Mathematical Literacy of Indigenous Students in Taiwan. International Research Journal of Sustainable Science \& Engineering. Volume 2 No.3. Hal $1-5$.

USAID, 2014. Bahan Rujukan bagi LPTK Praktik yang Baik dalam Pembelajarani Sekolah Dasar/ Madrasah Ibtidaiyah. Modul II.

Wray, D., et al. (2004). Teaching Literacy Effectively in the Primary School, London:Routledge Falmer.

Wiyanto. 2008. Menyiapkan Guru Sains Mengembangkan Kompetensi Laboratorium. Semarang: UNNES Press.

Yvette Solomon. 2009. Mathematical Literacy: Developing Identities of Inclusion. New York: Routledge 